\title{
Inverse correlation between serum albumin and serum lactate in adults with dengue
}

\author{
Ifael Yerosias Mauleti*, Suhendro*, Leonard Nainggolan*, and Martin Rumende*
}

\section{ABSTRACT}

Department of Internal Medicine, Faculty of Medicine,

University of Indonesia-

RSUPN Cipto Mangunkusumo,

Jakarta, Indonesia

Correspondence :

dr. Ifael Yerosias Mauleti, SpPD

Department of Internal Medicine, Faculty of Medicine,

University of Indonesia-

RSUPN Cipto Mangunkusumo,

Jakarta, Indonesia

Email: ifaelbsdpapdi@gmail.com

Univ Med 2016;35:75-80

DOI: 10.18051/UnivMed.2016.v35.75-80 pISSN: 1907-3062 / eISSN: 2407-2230

This open access article is distributed under a Creative Commons Attribution-Non Commercial-Share Alike 4.0 International License

\section{BACKGROUND}

Dengue infection is an acute viral infection, in the natural history of which plasma leakage may occur, resulting in shock followed by tissue hypoxia, with death as the final outcome if not treated properly. The purpose of this study was to determine the correlation of the hematocrit, serum albumin concentration, and the presence of pleural effusion or ascites, with hyperlactatemia in adult dengue patients.

\section{METHODS}

A cross-sectional study was conducted on 62 subjects. The inclusion criteria were: diagnosed dengue viral infection, age $>14$ years, fever during three consecutive days, and hyperlactatemia. Serum albumin was measured on an Advia 1800 analyzer using the bromocresol green method. The lactate oxidase method was used to determine serum lactate levels. Pleural effusion and/or ascites was determined using an ultrasound scanner (Xario SSA-660 A, Toshiba, Japan). The Pearson correlation test was used to analyze the data.

\section{RESULTS}

There was no significant correlation between the hematocrit $(r=0.11$; $\mathrm{p}=0.301)$, serum albumin $(\mathrm{r}=0.003 ; \mathrm{p}=0.981)$, and pleural effusion or ascites $(\mathrm{r}=0.75 ; \mathrm{p}=0.692)$ with serum lactate levels. However, in patients aged $>30$ years there was a significant inverse correlation between serum albumin and lactate levels ( $\mathrm{r}=-0.663 ; \mathrm{p}=0.026)$.

\section{CONCLUSION}

This study demonstrated a significant inverse correlation between albumin and serum lactate levels in dengue patients aged $>30$ years. This can aid in the early recognition and prompt management of at-risk patients to reduce morbidity and mortality.

Keywords: Dengue infection, serum lactate level, hematocrit, albumin, adult dengue patients 


\section{INTRODUCTION}

According to data for the year 2013, the number of dengue hemorrhagic fever (DHF) cases in Indonesia was 101,218, with an incidence rate of 41.25/100,000 inhabitants, and a case fatality rate of $0.7 \%$, while the numbers of provinces and districts or cities with dengue infections were 33 (100\%) and $436(87.73 \%)$, respectively. ${ }^{(1,2)}$

Infection with dengue virus may present with a wide clinical spectrum of symptoms, from asymptomatic to symptomatic (dengue fever/DD, DHF, dengue shock syndrome/DSS). ${ }^{(3,4)}$ Plasma leakage occurs in the critical phase, i.e. on days 3 to 5 of fever, thus lasting 2 times 24 hours. ${ }^{(5,6)}$ If the occurrence of plasma leakage is not recognized earlier and appropriate fluid therapy is not immediately instituted, the complication of dengue hemorrhagic fever, i.e. dengue shock syndrome, will follow, thus increasing the mortality rate of patients with dengue hemorrhagic fever. ${ }^{(7,8)}$ Plasma leakage resulting in tissue hypoxia is determined from the hematocrit (ht) and plasma protein concentration (especially albumin), and from the presence of pleural effusion and/or ascites upon imaging, using both plain $\mathrm{X}$-rays of the thorax and ultrasonography of the abdomen. ${ }^{(9-}$ ${ }^{12)}$ The study of Santosa et al. ${ }^{(11)}$ on children with hemorrhagic fever showed an increase in the hematocrit of $20 \%$ or higher, which value is currently considered to indicate the occurrence of significant plasma leakage, and was found to correspond to a serum lactate level of $>2.4 \mathrm{mmol} /$ L (sensitivity $79.31 \%$, specificity $77.42 \%$ ). The conclusion of abovementioned study was that serum lactate level may be used to determine the occurrence of significant plasma leakage in children with dengue hemorrhagic fever. Plasma leakage is defined as an increase in hematocrit of $\geq 20 \%$ above the reference range or the presence of clinical evidence of fluid accumulation. ${ }^{(13)}$ The advantage of determining serum lactate level is that a single assessment can be used for early recognition of plasma leakage, which usually occurs on days 3 to 5 of fever, and for evaluation of the adequacy of fluid therapy in patients with dengue hemorrhagic fever. ${ }^{(11,14)}$ Studies such as that of Santosa et al. ${ }^{(11)}$ have never been performed on adult patients with dengue infection. No information has been found about clinical studies on the hematocrit, serum albumin concentration, pleural effusion and/or ascites for determination of tissue hypoxia as a result of early plasma leakage in adult patients with dengue infection. Therefore the purpose of the present study was to determine the occurrence of tissue hypoxia as a result of early plasma leakage in adult patients with dengue infection by assessment of the hematocrit, serum albumin concentration, pleural effusion and/or ascites, and by testing their correlation with the serum lactate level.

\section{METHODS}

\section{Research design}

This study was of cross-sectional design and was carried out by collecting data from the medical records of patients with dengue infection who had attended Cipto Mangunkusumo National Central General Hospital, Jakarta and Persahabatan Central General Hospital, Jakarta, from 1 April 2014 until 15 March 2015.

\section{Subjects of the study}

Data collection was performed by consecutive non-random sampling. The inclusion criteria were patients with a diagnosis of dengue virus infection, aged $>14$ years, with 3 days fever, and hyperlactatemia. The exclusion criteria were patients with cancer, congestive heart failure, chronic obstructive pulmonary disease, anemia, pneumonia, pericarditis, pleuritis, chronic renal disease, sepsis, hepatic cirrhosis, and undernutrition.

The sample size was determined with the correlation coefficient formula, ${ }^{(15,16)}$ i.e.

$$
\mathrm{n}=\left(\frac{\mathrm{z}_{1-\alpha / 2}+\mathrm{z}_{1-\beta}}{0.5 \ln [(1+\mathrm{r}) /(1-r)]}\right)^{2}+3
$$

where $\mathrm{n}=$ sample size, $\mathrm{Z}_{1-\alpha / 2}=1.96, \mathrm{Z}_{1-\beta}=0.1$, and $r=0.4$. The minimum total sample size required was 62 patients. 


\section{Laboratory and ultrasonographic investigations}

Dengue NS-1 antigen was detected using Standard Diagnostics dipsticks, yielding either positive or negative results. The hematocrit was determined on a Sysmex XE - 2100 hematology analyzer by the impedance method, with the flowcytometric results expressed as percentages (\%). Serum albumin was determined on an Advia 1800 analyzer by the bromocresol green method and the results expressed in $\mathrm{g} / \mathrm{dL}$. Serum lactate concentration was measured on the Advia 1800 analyzer by the lactate oxidase method and the results expressed in mmol/L. Serum glutamic oxaloacetic transaminase (SGOT) and serum glutamic pyruvic transaminase (SGPT) concentrations were determined on a Cobas 501 analyzer using an enzymatic method and the results expressed in U/l. Pleural effusion and ascites were determined using an ultrasound scanner (Xario SSA-660 A, Toshiba, Japan) with the results given as present or absent.

\section{Ethical clearance}

This study obtained ethical clearance from the Health Research Ethics Committee, Faculty of Medicine, University of Indonesia, under no. 549/UN2.F1/ETIK/2015.

\section{Data analysis}

The Kolmogorov-Smirnov test was used to determine the normality of the hematocrit and serum albumin data. To determine a correlation of the hematocrit, serum albumin concentration, pleural effusion and/or as cites with serum lactate concentration, the Pearson test was used. Data analysis was performed with a computer program. The statistical tests were said to be significant if $\mathrm{p}<0.05$

\section{RESULTS}

From a search of the medical records, 70 patients were found, but those meeting the inclusion criteria were only 62 in number. Among these, 20 patients came from Cipto
Mangunkusumo National Central General Hospital, Jakarta and 42 were from RSUP Persahabatan Central General Hospital, Jakarta. Among the selected subjects, there were 34 (55\%) males and $28(45 \%)$ females, with a mean age of $23.7 \pm 8.1$ years. After the subjects had been grouped according to age, the age group of $<20$ years had 25 patients (40\%), the age group of 20-29 years had 26 patients (42\%), the age group of 30-39 years 7 patients (11\%), the age group of $40-49$ years 3 patients (5\%) and the age group of 50-59 years 1 patient (2\%). Mean SGOT and SGPT concentrations were $80.6 \pm 77.7 \mathrm{U} / \mathrm{L}$ and $44.0 \pm 34.9 \mathrm{U} / \mathrm{L}$, respectively, while mean serum albumin and serum lactate concentrations were $3.9 \pm 0.3 \mathrm{~g} / \mathrm{dL}$ and $2.6 \pm 0.8 \mathrm{mmol} / \mathrm{L}$, respectively (Table 1).

In males, the hematocrit $(\mathrm{r}=0.235 ; \mathrm{p}=0.181)$ and serum albumin concentration $(\mathrm{r}=-0.116$; $\mathrm{p}=0.515$ ) were not significantly correlated with serum lactate level. A similar nonsignificant correlation was shown by the females. On subgroup analysis, the serum albumin concentration of patients aged $>30$ years had a significant inverse correlation with serum lactate level $(\mathrm{r}=-0.663 ; \mathrm{p}=0.026)$ (Table 2$)$. This inverse

Table 1. Distribution of general characteristics of subjects $(n=62)$

\begin{tabular}{lc}
\hline Variable & n \\
\hline Gender & \\
Male & $34(55 \%)$ \\
Female & $28(45 \%)$ \\
Age (years, meant SD) & $23.7 \pm 8.1$ \\
Age group (years) & \\
$<20$ & $25(40 \%)$ \\
$20-29$ & $26(42 \%)$ \\
$30-39$ & $7(11 \%)$ \\
$40-49$ & $3(5 \%)$ \\
$50-59$ & $1(2 \%)$ \\
Hematocrit (\%, mean \pm SD) & $40.5 \pm 4.6$ \\
SGOT U/L (mean \pm SD) & $80.6 \pm 77.7$ \\
SGPT U/L (mean \pm SD) & $44.0 \pm 34.9$ \\
Serum lactate m mo1/L (mean \pm SD) & $2.6 \pm 0.8$ \\
Serum albumin gdL (mean \pm SD) & $3.9 \pm 0.3$ \\
Pleural effusion/ascites (n, \%) & \\
Positive & $28(45.2)$ \\
Negative & $34(54.8)$ \\
\hline
\end{tabular}

Legend: \%: percentage, SD: standard deviation 
Table 2. Results of correlation analysis between subgroups and serum lactate level

\begin{tabular}{|c|c|c|}
\hline Variab el & $\mathbf{r}$ & $\mathbf{p}$ \\
\hline \multicolumn{3}{|l|}{$\overline{\text { Effusion (+) }}$} \\
\hline Hematocrit vs serum 1 actate & 0.078 & 0.692 \\
\hline Al butn in vs serum lactate & 0.063 & 0.750 \\
\hline \multicolumn{3}{|l|}{ Effusion (-) } \\
\hline Hematocrit vs serum 1 actate & 0.209 & 0.237 \\
\hline Al bum in vs serum lactate & -0.042 & 0.811 \\
\hline \multicolumn{3}{|l|}{ Males } \\
\hline Hematocrit vs serum 1 actate & 0.235 & 0.181 \\
\hline Album in vs serum lactate & -0.116 & 0.515 \\
\hline \multicolumn{3}{|l|}{ Fem ales } \\
\hline Hematocrit vs serum 1 actate & -0.045 & 0.819 \\
\hline Album in vs serum lactate & 0.113 & 0.568 \\
\hline \multicolumn{3}{|l|}{ Age $\leq 30$ years } \\
\hline Hematocrit vs serum 1 actate & 0.060 & 0.677 \\
\hline Al bum in vs serum lactate & -0242 & 0.087 \\
\hline \multicolumn{3}{|l|}{ Age $>30$ years } \\
\hline Hematocrit vs serum 1 actate & 0.340 & 0.306 \\
\hline Al bum in vs serum lactate & -0.663 & $0.026^{*}$ \\
\hline
\end{tabular}

correlation indicates that the decrease in serum albumin concentration was correlated with increased serum lactate level in subjects with dengue aged 30 years and over.

\section{DISCUSSION}

Tissue hypoxia may occur in patients with dengue infection who have plasma leakage, which frequently occurs in the critical phase, i.e. on days 3 to 5 of fever. ${ }^{(5,6)}$ If this tissue hypoxia is not recognized earlier, to be managed by appropriate and aggressive fluid therapy, it will increase the number of complications and the mortality rate of these patients. ${ }^{(7,8)}$

Currently serum lactate is used as a biomarker to evaluate tissue hypoxia in patients with sepsis. ${ }^{(16)}$ The serum lactate level of a patient is a biomarker for the severity of systemic hypoperfusion, and does not depend on organ failure and shock. ${ }^{(17)}$ Increases in arterial or central venous lactate level can also predict in-hospital mortality in a number of disorders, such as infection, sepsis, liver disease, trauma, and cardiac arrest. ${ }^{(18)}$ Our study results showed no relationship between the hematocrit and serum lactate level. To ascertain the presence of tissue hypoxia as a result of early plasma leakage in patients with dengue infection, the hematocrit has to be determined. ${ }^{(19,20)}$

In addition, to ascertain the presence of tissue hypoxia as a result of early plasma leakage, the serum albumin concentration has also to be assessed. On subgroup analysis, a statistically significant inverse correlation was found between serum albumin and serum lactate concentrations in patients $>30$ years of age. This signifies that a decrease in serum albumin concentration is accompanied by an increase in serum lactate level in patients with dengue aged 30 years and over. Before the present study was conducted, there was no information on studies of the relationship between serum albumin and lactate level in patients with dengue.

Patients with severe dengue frequently present with severe plasma leakage and severe organ involvement. The age of $>40$ years was independently associated with severe dengue in Thailand. ${ }^{(21)}$ This is consistent with a previous retrospective analysis from France, where plasma leakage was the most common presentation for adults with severe dengue and that the age of $>37$ years was a predictor of plasma leakage. ${ }^{(22)}$

One limitation of this study was its crosssectional design, which precludes any assumption of a cause-and-effect relationship. To clarify the role of serum lactate level as indicator of tissue hypoxia in patients with dengue infection, a cohort study should be conducted, so as to minimize the risk of missing data and reduce bias. The clinical implication of our study results is that in adult patients with dengue aged $>30$ years, serum lactate level should be determined as biomarker for detection of tissue hypoxia resulting from early plasma leakage. Use of this biomarker may facilitate early recognition and timely treatment of patients with severe dengue, thereby reducing mortality, hospital burden, and unnecessary hospitalizations as a result of dengue.

\section{CONCLUSIONS}

The present study identified a significant inverse correlation between serum albumin and lactate concentrations in adult patients with 
dengue infection aged $>30$ years. This can aid in the early recognition and prompt management of at-risk patients to reduce morbidity and mortality.

\section{CONFLICT OF INTEREST}

The authors declare that they have no competing interests.

\section{ACKNOWLEDGMENT}

The investigators thank the managing directors (chief executive officers) of Cipto Mangunkusumo National Central General Hospital (RSUPN Ciptomangunkusumo), Jakarta and Persahabatan Central General Hospital (RSUP Persahabatan), Jakarta, for permission to collect patient data in their respective hospitals.

\section{REFERENCES}

1. Kementrian Kesehatan Republik Indonesia. Profil Kesehatan Indonesia 2013. Jakarta: Kementrian Kesehatan Republik Indonesia 2013.

2. Karyanti MR, Uiterwaal CS, Kusriastuti R, et al. The changing incidence of dengue haemorrhagic fever in Indonesia: a 45-year registry-based analysis. BMC Infect Dis 2014;14: 412. DOI: $10.1186 / 1471-2334-14-412$.

3. Malavige GM, Fernando S, Fernando DJ, et al. Dengue viral infections. Postgrad Med J 2004;80:588-601.

4. Murray NEA, Quam MB, Wilder-Smith A. Epidemiology of dengue: past, present and future prospects. Clin Epidemiol 2013;5:299-309.

5. Martina BE, Koraka P, Osterhaus AD. Dengue virus pathogenesis: an integrated view. Clin Microbiol Rev 2009;22:564-81.

6. World Health Organization. Dengue guidelines for diagnosis, treatment, prevention and control. Geneva: World Health Organization;2013.

7. da Silva MMC, Gil LHVG, de Azevedo Marques ET Jr, et al. Potential biomarkers for the clinical prognosis of severe dengue. Mem Inst Oswaldo Cruz 2013;108:755-62.

8. Conroy AL, Gelvez M, Hawkes M, et al. Host biomarkers are associated with progression to dengue haemorrhagic fever: a nested casecontrol study. Int J Infect Dis 2015;40:45-53.

9. World Health Organization. Handbook for clinical management of dengue. Geneva: World Health Organization; 2012.

10. Yacoub S, Wills B. Predicting outcome from dengue. BMC Med 2014;12:147. DOI: 10.1186/ s12916-014-0147-9.

11. Santosa D, Alwi EH, Idjradinata PS. Validitas kadar laktat darah dalam mendeteksi kebocoran plasma pada infeksi virus dengue anak. Majalah Kedokteran Indonesia 2011;61:58-62.

12. Michels M, Sumardi U, de Mast Q, et al. The predictive diagnostic value of serial daily bedside ultrasonography for severe dengue in Indonesian adults. PLoS Negl Trop Dis 2013;7:e2277.

13. Thanachartwet V, Wattanathum A, Oer-areemitr $\mathrm{N}$, et al. Diagnostic accuracy of peripheral venous lactate and the 2009 WHO warning signs for identifying severe dengue in Thai adults: a prospective observational study. BMC Infect Dis 2016;16:46. DOI 10.1186/s12879-016-1386-5.

14. Puspanjono MT, Latie AT, Sastroasmoro S, et al. Comparison of serial blood lactate level between dengue shock syndrome and dengue haemorrhagic fever (evaluation of prognostic value). Paediatr Indones 2007;47:150-55.

15. Madiyono B, Moeslichan SMZ, Sastroasmoro $S$, et al. Perkiraan besar sampel. Dalam Sastroasmoro S, Ismael S, editors. Dasar-dasar metodologi penelitian klinis. $4^{\text {th }}$ ed. Jakarta: Sagung Seto 2011:p. 348-82.

16. Shapiro NI, Howell MD, Talmor D, et al. Serum lactate as a predictor of mortality in emergency department patients with infection. Ann Emerg Med 2005;45:524-8.

17. Mikkelsen ME, Miltiades AN, Gaieski DF, et al. Serum lactate is associated with mortality in severe sepsis independent of organ failure and shock. Crit Care Med 2009;37:1670-7.

18. Okorie ON, Dellinger P. Lactate: biomarker and potential therapeutic target. Crit Care Clin 2011; 27:299-326.

19. de Azeredo EL, Monteiro RQ, de-Oliveira Pinto LM. Thrombocytopenia in dengue: Interrelationship between virus and the imbalance between coagulation and fibrinolysis and inflammatory mediators. Mediators Inflamm 2015; Article ID 313842, 16 pages http://dx.doi.org/10.1155/2015/313842.

20. Balasubramanian S, Janakiraman L, Kumar SS, et al. A reappraisal of the criteria to diagnose plasma leakage in dengue hemorrhagic fever. Indian Pediatr 2006;43:334-9. 
21. Thanachartwet V, Oer-areemitr N, Chamnanchanunt $S$, et al. Identification of clinical factors associated with severe dengue among Thai adults: a prospective study. BMC Infect Dis 2015;15:420. DOI: 10.1186/s12879015-1150-2.
22. Thomas L, Brouste Y, Najioullah F, et al. Predictors of severe manifestations in a cohort of adult dengue patients. J Clin Virol 2010;48: 96-9. 